\title{
Maurits Berger, De laatste shariarechtbank van Europa, Reisverslag van een juridische zoektocht
}

\author{
Irawan Sewandono
}

Maurits Berger, De laatste shariarechtbank van Europa, Reisverslag van een juridische zoektocht (Den Haag: Boom juridisch), 2019, ISBN 97-894-6290-708-9, 110 p.

Het boek van Berger is een luchtige en speelse noot bij het arrest in de zaak van de weduwe van Mola Sali tegen Griekenland (EHRM 19 december 2018, 20452/14, EHRC 2019/62). Hij zoekt antwoord op de volgende vragen: Is arbitragerechtspraak in sharia familie- en erfrecht in Nederland mogelijk? Mag het wel? Hoe verhouden wij ons tot religie in het algemeen, en religieus recht in het bijzonder? Het boek geeft historische achtergrondinformatie (p. 14-30), de hoofdlijnen van de algemene sharia inzake familie- en erfrecht (p. 35-52) en de status van minderheden in het Ottomaanse rijk (p. 67-73). Het is doorspekt met kleurrijke portretten en anekdotes. Deze brochure mondt uit in een advies aan Nederlandse beleidsmakers: laten we een instituut oprichten voor Nederlands islamitisch familierecht (dus geen erfrecht: p. 94-100).

Hier volgt de kern van het EHRM-arrest. Moustafa Mola Sali was een West-Thracische moslim die alles wat hij bezat - en dat was niet weinig - bij testament had nagelaten aan zijn weduwe. Dit testament was opgemaakt conform het Griekse Burgerlijk Wetboek (r.o. 9). Naar sharia-erfrecht zou in dit geval, omdat er geen kinderen waren, slechts een kwart aan zijn weduwe toekomen en - als ik het goed het begrepen - de rest aan haar twee schoonzusters (r.o. 36). In eerste aanleg visten deze schoonzusters achter het net, maar daarna keerde het tij. Naar vaste rechtspraak van de Griekse Hoge Raad was de nalatenschap - voor zover onbezwaard - van deze moslims uitsluitend onderworpen aan shariarecht (r.o. 55). Volgens het EHRM mag de toepassing van shariarecht echter niet in strijd komen met internationale en Europese mensenrechtenverdragen van na 1948 (r.o. 154). Ook mag een bijzondere status voor een nationale minderheid niet leiden tot discriminatie (r.o. 155). Bescherming van de identiteit van een minderheidsgroep mag niet ten koste gaan van het recht van zijn individuele leden om ervoor te kiezen niet tot die groep te behoren of niet zijn gebruiken en regels te volgen (r.o. 156). Als begunstigde van een testament opgemaakt door een islamitische erflater en in overeenstemming met het Griekse BW wordt deze weduwe anders behandeld dan een begunstigde van een dergelijk testament opgemaakt door een niet-islamitische erflater. Voor dit verschil in behandeling is geen rechtvaardiging (r.o. 161).

Enige kennis van de moderne Griekse geschiedenis is noodzakelijk om de gevoeligheden rond deze moslimminderheid te kunnen begrijpen. De achtergebleven moslims in de provincie West-Thracië zijn een restant van de Ottomaanse veel- 
volkerenstaat van voor de Eerste Wereldoorlog. In mijn werkkamer hangt een ingekleurde gravure van de Balkan omstreeks 1850. Daarop is Griekenland nog niet veel meer dan Athene en de Peloponnesos. De havenstad Thessaloniki, Noord- en Zuid-Macedonië en Oost- en West-Thracië waren toen nog deel van het Osmaanse rijk. Op de Balkan en in Klein-Azië leefden orthodoxe christenen en moslims door elkaar, enerzijds Grieken, Bulgaren, Serven en Macedoniërs, anderzijds Turken, Albanezen en Pomaken. In deze veelvolkerenstaat genoten die godsdienstige en taalkundige minderheden enige autonomie. Hun eigen leiders waren aanspreekpunt voor Istanbul. Zolang zij ervoor zorgden dat er voldoende belasting werd betaald, liet de Porte de minderheden met rust (het millet-stelsel, p. 26). Over de Balkan bleef het Congres van Wenen (1814-1815) oorverdovend stil. Daarna viel het Ottomaanse rijk geleidelijk uit elkaar. Dit kostte ruim anderhalve eeuw en ging gepaard met veel oorlogen en etnische zuiveringen. In de twee Balkanoorlogen (1912-1913) trokken Grieken, Bulgaren, Serven en Albanezen eerst gezamenlijk op tegen de Turken en daarna vochten ze met dezelfde strijdlust tegen elkaar. Bulgarije en Griekenland aasden op Thessaloniki en Macedonië. Servië, de derde partij, wist het noordelijke deel te bemachtigen en Griekenland het zuidelijke. Daarop verjoegen de eerste twee partijen de Bulgaren uit de omgeving van Thessaloniki. Bulgarije moest zich tevreden stellen met West-Thracië. Wrokkend sloot het zich in de Eerste Wereldoorlog aan bij Duitsland, Oostenrijk en Turkije. Na deze wereldoorlog moest het als verliezende partij West-Thracië aan Griekenland afstaan en verloor het zijn toegang tot de Middellandse Zee. Griekenland en Turkije gingen nog even door in Klein-Azië. Dit eindigde met de val van Smyrna (het huidige Izmir), de Griekse teruggave van Oost-Thracië aan Turkije en de verdrijving van christenen uit Klein-Azië. Het werd bezegeld met de uitwisseling van anderhalf miljoen christenen tegen een half miljoen moslims (eveneens p. 26). Door veel Griekstaligen te herhuisvesten in Zuid-Macedonië werd dat gebied definitief gehelleniseerd (zie Wikipedia, Ottomaanse rijk, kaart van de territoriale expansie van Griekenland 1832-1947 en uitgebreider dan Berger: Mark Mazower, The Balkans (Londen: Phoenix Press 2001), Richard Clogg, A Concise History of Greece (Cambridge UP 1992)).

De moslims in West-Thracië waren uitdrukkelijk uitgezonderd van de GrieksTurkse bevolkingsuitwisseling. Ze hebben ook nu nog hun eigen scholen en familie- en erfrecht behouden (Verdrag van Lausanne 1923, EHRM-arrest r.o. 65). Als deze moslims hun geschillen aan de plaatselijke moefti voorleggen, blijft shariarecht buiten toepassing voor zover zijn regels in strijd zijn met de Griekse openbare orde. Dat wil zeggen dat de rechtbank geen beslissingen uitvoerbaar verklaart als dat leidt tot polygamie, huwelijkssluiting door minderjarigen zonder rechterlijke toestemming of buiten aanwezigheid van een van de partners en verstoting (EHRM-arrest r.o. 73, v.g.l. art. 10:32 Ned. BW). Strikt genomen is de moefti geen rechtbank, maar een vorm van arbitrage. Zijn oordelen in zaken waarin zijn bevoegdheid wordt betwist, zijn geen res judicata zolang ze nog niet uitvoerbaar zijn verklaard door de Griekse staatsrechtbank (Berger, p. 11 en 27, art. 11 lid 9 Grieks-Turkse Vredesverdrag van Athene 1913 en EHRM-arrest r.o. 
43 en 63). Spreken van de laatste shariarechtbank in Europa is dus enigszins misleidend.

De bijzondere positie van de Thracische moslims spruit voort uit het Ottomaanse millet-stelsel. Hun rechten zijn bevroren naar de situatie aan het begin van de twintigste eeuw (daarna hebben overigens de ontwikkelingen in Turkije zelf niet stilgestaan, p. 68). Deze bijzondere rechten strekken tot bescherming van de identiteit van deze nationale minderheid. Wie tot deze groep behoort, bleef tot voor kort onderworpen aan het shariafamilie- en erfrecht. Opting out was onmogelijk tot 15 januari 2018. Sindsdien is het gewone Griekse BW regel. Shariafamilierecht wordt nu alleen nog met instemming van partijen toegepast en shariaerfrecht alleen als de erflater daarvoor heeft gekozen (EHRM-arrest r.o. 57 en 160). Opting in is nog steeds niet mogelijk: bekeerlingen en moslims van elders bleven en blijven buitenstaanders (p. 85-88). Afgezien van bijzonder onderwijs denken wij in Nederland, net als de Europese rechters, bij godsdienstvrijheid eerder aan respect voor individuele uitingen (p. 90-91), zoals (ECLI:NL:CRVB: 2019:480, baard bij asbestverwijdering), (ECLI:NL:CRVB:2019:481, moskeebezoek vrijdagmiddag) en (ECLI:EU:C:2017:203 en ECLI:EU:C:2017:204, hoofddoek tijdens werk).

Er is een opmerkelijk verschil tussen het West-Thracische moslimrecht en de traditionele Arabische sharia. Daar worden geschillen beslecht door de kadi, de wijze man die partijen hoort en knopen doorhakt, zo nodig na raadpleging van de moefti, de islamitische Schriftgeleerde. In de Ottomaanse traditie en dus ook hier in Thracië is de moefti tevens kadi en vertegenwoordigt hij de lokale gemeenschap (p. 35). Een twistappel is nog of de moefti door de Griekse moslims mag worden gekozen dan wel van overheidswege moet worden benoemd (p. 63 en 79-88). Bij verdeeldheid binnen een religieuze gemeenschap moet de overheid zich beperken tot het zekerstellen dat de betrokken groeperingen elkaar tolereren (r.o. 53, EHRM 14 december 1999, Serif, 38178/97).

Een ander verschil tussen West-Thracië en de hedendaagse moslimstaten in Azië en Afrika is dat deze nu ieder hun eigen moderne huwelijkswetgeving kennen. Het familie- en erfrecht van de Griekse moslimminderheid is daarentegen, net als in de Ottomaanse tijd, alleen te kennen uit de verzamelde oordelen van de moefti (p. 52-53). Overigens staat ook in West-Thracië de tijd niet stil. Waar Thracische moslims vroeger voor vervolgonderwijs naar Turkije gingen, gaan zij nu vaak eerst naar Griekstalige scholen in hun eigen provincie en vervolgens naar de universiteit in Thessaloniki of Athene (p. 28-31, 61-63 en 85).

Die Thracische sharia is niet te vergelijken met de polygamie en lijfstraffen van de hedendaagse barbaarse rechtspraak in diverse Aziatische en Afrikaanse moslimlanden. Het heeft hooguit een beetje gemeen met het inheemse gewoonterecht zoals dat in de eerste helft van de twintigste eeuw is opgetekend en toegepast in de Engelse, Franse en Nederlandse koloniën (zie hierover A.K.J.M. Strijbosch, Juristen en de studie van volksrecht in Nederlands-Indie en anglofoon Afrika (Nijmegen: Instituut voor volksrecht 1980)). 
Het lezenswaardige boek van Berger werpt een frisse blik op de sharia. Oprichting van een Nederlandse kennisinstituut voor shariafamilierecht is een goede zaak. Hetzelfde geldt voor een geschillencommissie. Maar laat dit in vredesnaam over aan jonge en verstandige Turkse en Marokkaanse Nederlanders met de nodige praktische kennis en ervaring op het gebied van het internationaal privaatrecht van Boek 10 van het BW, alsmede goed bestuurlijk en psychologisch inzicht en laat Nederlandse politici zich verre hiervan houden. Van beide zijden trekken dergelijke goedbedoelde projecten de verkeerde mensen aan. Hun wederzijdse afhankelijkheid en onbegrip hebben al menige instelling voor onderwijs, zorg of erfgoedbeheer te gronde gericht. 